\title{
Atretic parietal encephalocoele
}

\author{
Susana Franco Santos, ${ }^{1}$ Helena Ramos, ${ }^{2}$ Amets Irañeta, ${ }^{3}$ Carla Conceição ${ }^{3}$
}

${ }^{1}$ Hospital Dona Estefânia, Centro Hospitalar Lisboa Central, Lisboa, Portugal 2Department of Neonatal Intensive Care, Maternidade Dr Alfredo da Costa, Lisboa, Portugal

${ }^{3}$ Hospital Dona Estefania, Lisboa, Portugal

\section{Correspondence to} Dr Susana Franco Santos, susana.franco.santos85@ gmail.com

Accepted 19 June 2016
CrossMark

To cite: Santos $\mathrm{SF}_{\text {, }}$ Ramos H, Irañeta A, et al. BMJ Case Rep Published online: [please include Day Month Year] doi:10.1136/ bcr-2016-215812

\section{DESCRIPTION}

A midline posterior parietal cystic structure$2 \times 2 \mathrm{~cm}$-was diagnosed in a routine 22 -week ultrasonographic scan. It did not appear to have communication through parietal bone or with

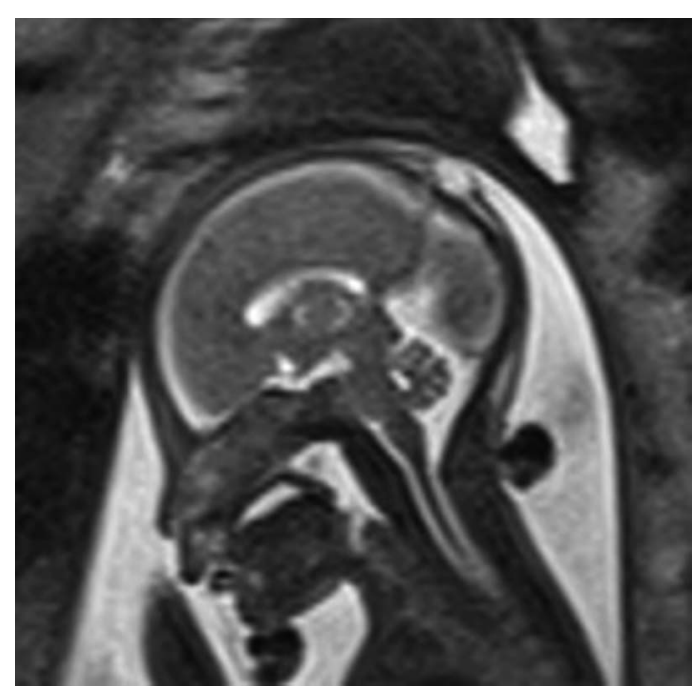

Figure 1 Subcutaneous formation in the medial line of the parieto-occipital.

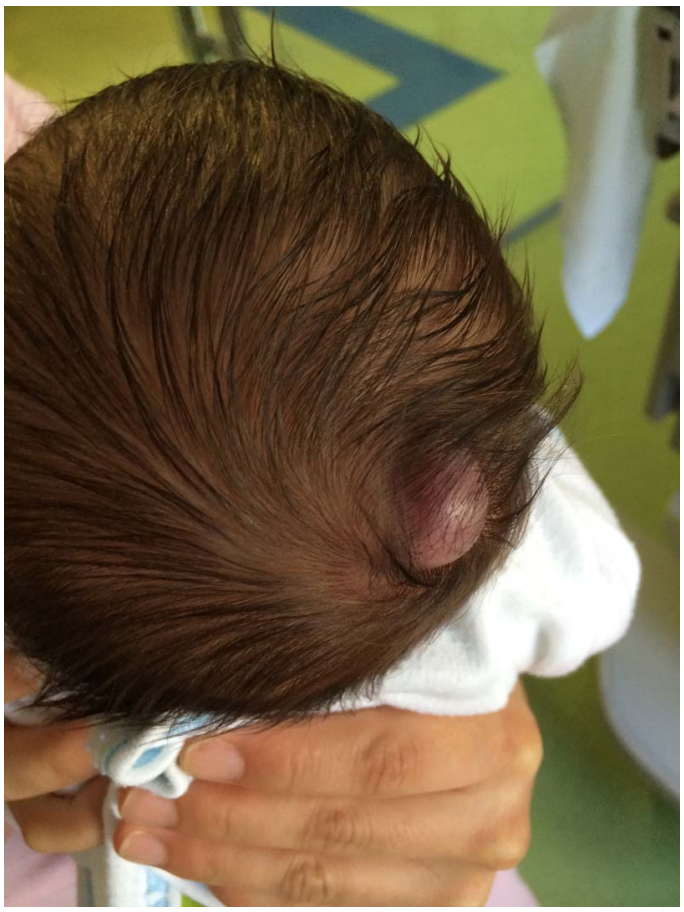

Figure 2 Tumefaction in the median line of the parieto-occipital suture. sutures of the brain compartment. In the 24th week, an MRI was performed, which confirmed the presence of a small subcutaneous formation in the medial line of the parieto-occipital transition, which did not seem to have macroscopic continuity with the cranial compartment. All brain structures were normal, except for vertical embryonic positioning of the straight sinus, so atretic parietal encephalocoele was suspected (figure 1).

Maternal history: the parents were nonconsanguineous. The mother, aged 29 years, was healthy, with no known history of drugs or alcohol consumption. She had had a normal pregnancy, with folic acid intake in the first trimester. First trimester combined tests performed at 12 weeks of pregnancy were negative.

A full-term male neonate was delivered by caesarean section at 39 weeks. His weight was $3030 \mathrm{~g}$ with an Apgar index 9/10. A small tumefaction $(2 \times 2 \mathrm{~cm})$ was seen in the median line of the parieto-occipital suture. It was covered by skin and hairs, and had a soft consistency (figure 2). This structure was easily depressed and became tense with valsalva manoeuvres. The rest of the physical examination was normal, including neurological examination. An after birth MRI clearly showed an underlying very small bone defect and the definitive diagnosis of posterior interparietal epicranial atretic encephalocoele was made (figure 3).

At 2 months, the infant had a surgery performed where the atretic encephalocoele was successfully

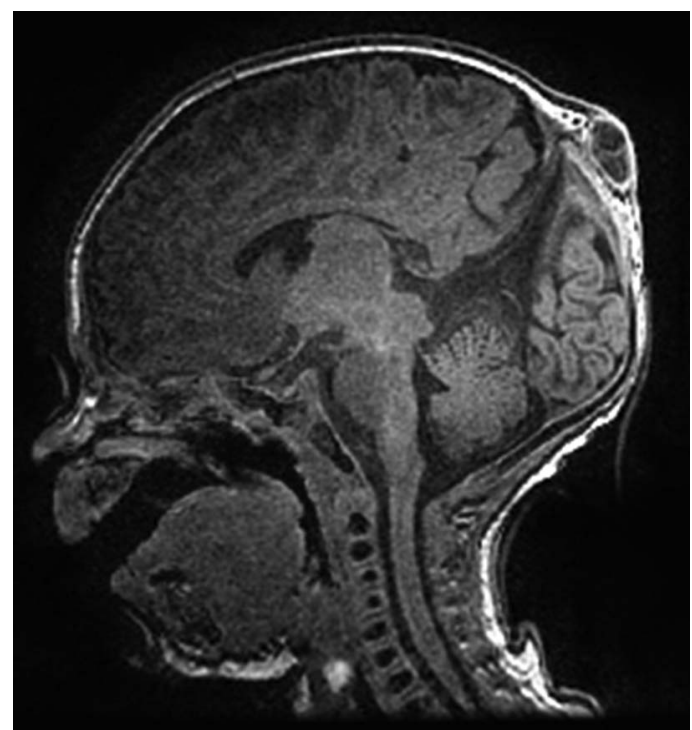

Figure 3 Posterior interparietal epicranial atretic encephalocoele. 


\section{Learning points}

- Atretic cephalocoele is a meningeal sac with degenerated neural tissue. It represents the remnant nuchal blebs that may relate to transient overdistension of the rhombencephalic vesicle. There are small, skin covered subscalp lesions that can contain meninges, neural and glial rests. They have been termed as atypical or rudimentary meningocoeles, meningeal heterotopias and meningocoele manque. These generally occur within a few centimetres of the $\lambda$ and contain meninges and neural rests, with approximately half the reported cases being parietal in location. Their recognition is important as their prognosis differs. $^{1-4}$

- Prenatal ultrasonography detects the vast majority of cases (almost 80\%), but neonatal MRI will sometimes establish not only the definitive diagnosis and also the prognosis, as it will clearly reveal the structures involved and the presence or absence of hydrocephalus. ${ }^{5}$

- Diagnosis of these covered lesions is between encephalocoele, meningocoele, atretic encephalocoele, sinus pericranii, haemangioma, epidermal cyst and teratoma and cystic hygroma. ${ }^{2}$ removed without complications. The histological results confirmed the diagnosis and today the patient is a healthy 9-month old boy.

Contributors SFS is the guarantor and was involved in the identification of the case, idea for the article, literature research and writing of the manuscript. SFS and $\mathrm{HR}$ were involved in the management of the case. $C C$ contributed the MRI reports and $\mathrm{Al}$ was the neurosurgeon.

Competing interests None declared.

Patient consent Obtained.

Provenance and peer review Not commissioned; externally peer reviewed.

\section{REFERENCES}

1 Muralidharan CG, Aggarwal R, Singh D, et al. Atretic parietal encephalocoele-an unusual diagnosis. Med J Armed Forces India 2013;69:83-5.

2 Patterson RJ, Egelhoff JC, Crone KR, et al. Atretic parietal cephaloceles revisited: an enlarging clinical and imaging spectrum? AJNR Am J Neuroradiol 1998; 19:791-5.

3 Rich P, Jones R, Britton J, et al. MRI of the foetal brain. Clin Radiol 2007;62:303-13.

4 Martinez-Lage JF, Sola J, Casas C, et al. Atretic cephalocele: the tip of the iceberg. J Neurosurg 1992;77:230-5.

5 Boyd PA, Wellesley DG, De Walle HE, et al. Evaluation of the prenatal diagnosis of neural tube defects by fetal ultrasonographic examination in different centres across Europe. J Med Screen 2000;7:169-74.

Copyright 2016 BMJ Publishing Group. All rights reserved. For permission to reuse any of this content visit http://group.bmj.com/group/rights-licensing/permissions.

BMJ Case Report Fellows may re-use this article for personal use and teaching without any further permission.

Become a Fellow of BMJ Case Reports today and you can:

- Submit as many cases as you like

- Enjoy fast sympathetic peer review and rapid publication of accepted articles

- Access all the published articles

- Re-use any of the published material for personal use and teaching without further permission

For information on Institutional Fellowships contact consortiasales@bmjgroup.com

Visit casereports.bmj.com for more articles like this and to become a Fellow 